\title{
Studies on Haemoglobin, Serum Calcium and Ascorbic Acid Level in Normal Pregnant, Pre-Eclamptic and Eclamptic Patients.
}

\author{
Khursheed Jahan ${ }^{1}$, Maksuda Parvin ${ }^{1}$ and Abdullah Ibn Mafiz ${ }^{2} *$ \\ Institute of Nutrition and Food Science, University of Dhaka ${ }^{1}$ \\ Mawlana Bhashani Science and Technology University, Tangail ${ }^{2}$
}

\begin{abstract}
:
Background: Nutritional status in relation to selected biochemical parameters and also nutrient intakes in the pre-eclampsia and eclampsia was assessed in 52 patients and compared with that of 52 normal pregnant (NP) women. Serum calcium, ascorbic acid and blood Hb levels in the pre-eclamptic and eclamptic patients were significantly lower than the values of NP women. By unpaired t-test demonstrated in our study, the serum calcium, ascorbic acid and blood Haemoglobin (Hb) level were highly significantly different but not correlated with each other when compared among these groups. However, total statistical analysis revealed that among all the factors studied serum calcium level, ascorbic acid level and blood $\mathrm{Hb}$ level have effect on nutritional status of pre-eclampsia and eclampsia.
\end{abstract}

Key Words: Nutritional Status, Pre-eclampsia, Eclampsia, Serum Calcium and Serum Ascorbic Acid.

\section{Introduction:}

Toxaemia of pregnancy means combination of symptoms including hypertension, oedema and albuminuria and can be classified into two types: one is pre-eclampsia and the other is eclampsia.

The United Kingdom obstetrics medical research unit has adopted the working definition of pre-eclampsia as "A rise in diastolic blood pressure to $90 \mathrm{~mm}$ of mercury or higher after $24^{\text {th }}$ week of pregnancy, without proteinuria (mild preeclampsia) or with definite proteinuria not attributable to infection (Severe Preeclampsia)." 1

Toxaemia of pregnancy is one of the major problems in developing country. Many factors; e.g. maternal and nutritional factors influence pre-eclampsia and eclampsia, and poor nutritional status during pregnancy has important consequences. Several studies has reported that inadequate supply of nutrients during pregnancy may lead to development of pre-eclampsia and eclampsia., ${ }^{2,3}$ But most of the studies aimed

Bangladesh Journal of Nutrition. Vol. 24-25 December, 2011-2012. Institute of Nutrition and Food Science, University of Dhaka, Dhaka-1000, Bangladesh. 
* Author for Correspondence

at understanding various aspects of the problem have been carried out on pregnant woman as they have been identified as the vulnerable group in Bangladesh. Preeclampsia and eclampsia continue to be an important cause of maternal and perinatal mortality in most of the unprivileged areas of the world. ${ }^{5}$

\section{Methods and Materials:}

\section{Type of Study:}

A cross sectional sample survey was carried out among the normal pregnant woman, pre-eclamptic and eclamptic patients aged between 15-16 years and admitted in Dhaka Medical College hospital and Sir Solilmullah Medical College Hospital.

\section{Study Population:}

The study population comprised woman with pre-eclampsia , eclampsia and normal pregnancy.

\section{Sample Size:}

The following formula was used to calculate the sample size:

$\mathrm{n}=16 \mathrm{P}(100-\mathrm{P}) / \mathrm{W}^{2}$

Where,

$\mathrm{n}=$ Number of sample

$\mathrm{P}=$ Prevalence rate which was calculated from record book of 2007 in eclampsia and department of obstetrics and gynaecology ward in $\mathrm{DMCH}$.

$\mathrm{W}=$ Width of number

\section{Study Subjects:}

The total sample size was 104 . The control group consists of normal pregnant woman ( $\mathrm{n}=52)$ and the study group was divided into pre-eclamptic $(\mathrm{n}=26)$ and eclamptic $(n=26)$ patients.

\section{Study Design:}

The nutritional status was assessed cross sectionally on fifty two ( $n=52)$, who contributed a blood sample during 20-40 weeks of gestation. They were divided into two sub groups: pre-eclampsia $(n=26)$ and eclampsia $(n=26)$; and then compared with 52 normal pregnant woman with same of gestational age (20-40 weeks) and same age group (15-40 years). 


\section{Research Instruments:}

A questionnaire was developed to obtain relevant information and then data were collected with maximum precaution.

\section{Collection of Data and Specimens:}

Anthropometric data of body weight, height and foetus weight and simultaneously blood pressure information were collected. Socio-economic information also collected. Blood samples were collected between 8:00 am and 10:30 am.

\section{Analytical Methods:}

Estimation of Haemoglobin: Hb level was determined according to the method of Cartwright, using a commercial kit. ${ }^{8}$

Estimation of Serum Calcium: Serum calcium was estimated by colorimetric method. ${ }^{9}$

\section{Estimation of Serum of Ascorbic Acid:}

Serum ascorbic acid was measured by dinitrophenyl hydrazine method with modification according to Lowry et al. ${ }^{10}$

\section{Statistical Analysis:}

Statistical analysis was done by using SPSS 12 windows program. Appropriate Statistical analysis was performed by using t-test for paired data. Values were considered significant at $\mathrm{p}<0.05$. Results were expressed as mean $\pm \mathrm{SD}$.

\section{Results:}

Among the pre-eclamptic patients, $19.2 \%$ were in the age group above 30 years. About $42.3 \%$ were in age group 25 to 29 years, 34.6\% were $20-24$ years and only $3.8 \%$ were below 20 years of age group. In case of eclamptic patients $15.4 \%$ were in the age group above 30 years. About $42.3 \%$ were in age group 25 to 29 years, $42.3 \%$ were $20-24$ and there was none in age group below 20 years. About $57.7 \%$ pre-eclamptic patients were naliparous and $42.3 \%$ were multiparous but for eclamptic patients the values were $46.1 \%$ and $53.8 \%$ respectively. Some $50 \%$ of the pre-eclamptic patient's family income was above 1000 TK per month but for eclamptic patients it was $38.5 \%$. About $3.8 \%$ pre-eclamptic patients were illiterate but there were no illiterate eclamptic patients. There was no still birth by eclamptic patients. About $53.85 \%$ of the pre-eclamptic patients and $65.4 \%$ eclamptic patients gave birth to underweight baby. 
Table 1: Number and percentage distribution of normal pregnant women, preeclamptic and eclamptic patients by age, parity, family income, educational level and status of foetus

\begin{tabular}{|c|c|c|c|c|c|c|c|}
\hline \multirow{2}{*}{ Variable } & \multirow{2}{*}{ Category } & \multicolumn{2}{|c|}{$\begin{array}{c}\text { Normal } \\
\operatorname{pregnant}(n=52)\end{array}$} & \multicolumn{2}{|c|}{$\begin{array}{c}\text { Pre-eclampsia } \\
\qquad(n=26)\end{array}$} & \multicolumn{2}{|c|}{ Eclampsia $(n=26)$} \\
\hline & & Number & $\%$ & Number & $\%$ & Number & $\%$ \\
\hline \multirow{4}{*}{ Age } & $<20$ & 2 & 3.8 & 1 & 3.8 & - & - \\
\hline & $20-24$ & 15 & 28.8 & 9 & 34.6 & 11 & 42.3 \\
\hline & $25-29$ & 19 & 36.5 & 11 & 42.3 & 11 & 42.3 \\
\hline & $>30$ & 16 & 30.8 & 5 & 19.2 & 4 & 15.4 \\
\hline \multirow[b]{2}{*}{ Parity } & Naliparous & 33 & 63.4 & 15 & 57.7 & 12 & 46.1 \\
\hline & Multiparous & 19 & 36.5 & 11 & 42.3 & 14 & 53.8 \\
\hline \multirow{3}{*}{$\begin{array}{c}\text { Family } \\
\text { income } \\
(\mathrm{Tk})\end{array}$} & $<6000$ & 6 & 11.5 & 5 & 19.2 & 7 & 26.9 \\
\hline & 6000-9999 & 26 & 50.0 & 8 & 30.8 & 9 & 34.6 \\
\hline & $>10000$ & 20 & 38.5 & 13 & 50 & 10 & 38.5 \\
\hline \multirow{4}{*}{$\begin{array}{l}\text { Educational } \\
\text { level }\end{array}$} & Illiterate & - & - & 1 & 3.8 & - & - \\
\hline & $\begin{array}{c}\text { Primary } \\
\text { incomplete }\end{array}$ & 3 & 5.8 & 6 & 23.1 & 6 & 23.1 \\
\hline & $\begin{array}{c}\text { Primary } \\
\text { complete }\end{array}$ & 33 & 63.5 & 13 & 50.0 & 14 & 53.8 \\
\hline & $\begin{array}{c}\text { Above } \\
\text { Secondary }\end{array}$ & 16 & 30.8 & 6 & 23.1 & 6 & 23.1 \\
\hline \multirow{3}{*}{$\begin{array}{l}\text { Status of } \\
\text { the foetus }\end{array}$} & Still Birth & - & - & 1 & 3.8 & - & - \\
\hline & Underweight & 14 & 26.9 & 14 & 53.8 & 17 & 65.4 \\
\hline & Normal & 38 & 73.1 & 11 & 42.3 & 9 & 34.6 \\
\hline
\end{tabular}

The BMI of the normal pregnant women ranged from 19.70 to 25.97 . The mean $( \pm S D)$ BMI of the normal pregnant women was $24.16( \pm 1.13)$ with a median of 24.42 . In case of pre-eclamptic and eclamptic patients the mean $( \pm$ SD) of BMI were $23.20( \pm 1.90)$ and 23.63 $( \pm 2.18)$ respectively. The mean $( \pm \mathrm{SD})$ of systolic pressure for pre-eclamptic and eclamptic patients were $130( \pm 19) \mathrm{mm}-\mathrm{Hg}$ and $138( \pm 19) \mathrm{mm}-\mathrm{Hg}$. For diastolic pressure it were 95 $( \pm 10) \mathrm{mm}-\mathrm{Hg}$ and $95( \pm 10) \mathrm{mm}-\mathrm{Hg}$. Haemoglobin level for pre-eclamptic patients ranged from $8.48 \mathrm{~g} / \mathrm{dl}$ to $10.00 \mathrm{~g} / \mathrm{dl}$ but for eclamptic patients it was $8.00-9.90 \mathrm{~g} / \mathrm{dl}$. The mean $( \pm \mathrm{SD})$ of serum ascorbic acid level for pre-eclamptic and eclamptic patients were 0.15 $( \pm 0.09) \mathrm{mg} / \mathrm{dl}$ and $0.11( \pm 0.06) \mathrm{mg} / \mathrm{dl}$ respectively. Serum calcium level for preeclamptic patients ranged from $7.31 \mathrm{mg} / \mathrm{dl}$ to $9.14 \mathrm{mg} / \mathrm{dl}$ but for eclamptic patients it was $7.09-8.97 \mathrm{~g} / \mathrm{dl}$. 
Rahman and Islam : Nutritional Status and Food Security

Table 2: Mean, median and range of BMI, blood pressure, haemoglobin, serum ascorbic acid and serum calcium

\begin{tabular}{|c|c|c|c|c|}
\hline Variable & Group & $\operatorname{Mean}( \pm S D)$ & Median & Range \\
\hline \multirow[t]{3}{*}{ BMI } & Normal pregnancy & $24.16 \pm 1.13$ & 24.42 & $19.70-25.97$ \\
\hline & Pre-eclampsia & $23.20 \pm 1.90$ & 23.19 & $18.18-25.80$ \\
\hline & Eclampsia & $23.63 \pm 2.18$ & 23.62 & $18.55-27.03$ \\
\hline \multirow[t]{3}{*}{ Systolic(mm-Hg) } & Normal pregnancy & $108 \pm 8$ & 110 & $90-130$ \\
\hline & Pre-eclampsia & $130 \pm 19$ & 130 & $100-180$ \\
\hline & Eclampsia & $138 \pm 19$ & 130 & $110-180$ \\
\hline \multirow[t]{3}{*}{ Diastolic(mm-Hg) } & Normal pregnancy & $77 \pm 9$ & 75 & $60-90$ \\
\hline & Pre-eclampsia & $95 \pm 10$ & 90 & $70-110$ \\
\hline & Eclampsia & $95 \pm 10$ & 90 & $75-115$ \\
\hline \multirow[t]{3}{*}{ Hemoglobin (g/dl) } & Normal pregnancy & $10.19 \pm 0.77$ & 10.08 & 8.64-11.79 \\
\hline & Pre-eclampsia & $9.49 \pm 0.35$ & 9.60 & $8.48-10.00$ \\
\hline & Eclampsia & $8.88 \pm 0.52$ & 8.96 & $8.00-9.90$ \\
\hline \multirow{3}{*}{$\begin{array}{l}\text { Serum ascorbic } \\
\text { acid(mg/dl) }\end{array}$} & Normal pregnancy & $0.34 \pm 0.22$ & 0.26 & $0.12-0.80$ \\
\hline & Pre-eclampsia & $0.15 \pm 0.09$ & 0.16 & $0.04-0.28$ \\
\hline & Eclampsia & $0.11 \pm 0.06$ & 0.08 & $0.05-0.22$ \\
\hline \multirow[t]{3}{*}{ Serum calcium (mg/dl) } & Normal pregnancy & $9.84 \pm 1.10$ & 9.97 & 8.32-11.64 \\
\hline & Pre-eclampsia & $8.24 \pm 0.81$ & 8.30 & $7.31-9.14$ \\
\hline & Eclampsia & $8.03 \pm 0.61$ & 8.03 & 7.09-8.97 \\
\hline
\end{tabular}

The differences between normal pregnant and pre-eclampsia patients were assessed using unpaired t-test. The pre-eclamptic patients had lower mean value for $\mathrm{Hb}$, serum ascorbic acid and serum calcium than normal pregnant women. The differences were highly significant for $\mathrm{Hb}$ and serum calcium but not statistically significant for serum ascorbic acid (Table 3). 
Table 3: Relationship between normal pregnant (NP) and pre-eclamptic (PEC) patients in respect of blood $\mathrm{Hb}$, serum ascorbic acid and serum calcium

\begin{tabular}{|c|c|c|c|}
\hline Variable & NP & PEC & P-value \\
Mean \pm SD & Mean \pm SD & \\
\hline $\mathrm{Hb}(\mathrm{g} / \mathrm{dl})$ & $10.19 \pm 0.77$ & $9.49 \pm 0.35$ & 0.00 \\
\hline Serum Ascorbic Acid (mg/dl) & $0.34 \pm 0.22$ & $0.15 \pm 0.09$ & 0.09 \\
\hline Serum calcium $(\mathrm{mg} / \mathrm{dl})$ & $9.84 \pm 1.10$ & $8.24 \pm 0.81$ & 0.01 \\
\hline
\end{tabular}

The differences between normal pregnant and eclampsia patients were assessed using unpaired t-test. The eclamptic patients had lower mean value for $\mathrm{Hb}$, serum ascorbic acid and serum calcium than normal pregnant women. The differences were highly significant for $\mathrm{Hb}$, serum calcium and serum ascorbic acid (Table 4).

Table 4: Relationship between normal pregnant (NP) and eclamptic (EC) patients in respect of $\mathrm{Hb}$, serum ascorbic acid and serum calcium

\begin{tabular}{|c|c|c|c|}
\hline Variable & $\begin{array}{c}\text { NP } \\
\text { Mean } \pm \text { SD }\end{array}$ & $\begin{array}{c}\text { EC } \\
\text { Mean } \pm \text { SD }\end{array}$ & P-value \\
\hline Hb (g/dl) & $10.19 \pm 0.77$ & $8.88 \pm 0.52$ & 0.00 \\
\hline $\begin{array}{c}\text { Serum Ascorbic Acid } \\
\text { (mg/dl) }\end{array}$ & $0.34 \pm 0.22$ & $0.11 \pm 0.06$ & 0.02 \\
\hline Serum calcium (mg/dl) & $9.84 \pm 1.10$ & $8.03 \pm 0.61$ & 0.00 \\
\hline
\end{tabular}

The differences between pre-ecampsia and eclampsia patients were assessed using unpaired t-test. The eclamptic patients had lower mean value for $\mathrm{Hb}$, serum ascorbic acid and serum calcium as compared to pre-eclampsic patients. The differences were highly significant only for $\mathrm{Hb}$, but not statistically significant for serum ascorbic acid and serum calcium (Table 5). 
Table 5: Relationship between preeclamptic (PEC) patients and eclamptic (EC) patients in respect of $\mathrm{Hb}$, serum ascorbic acid and serum calcium

\begin{tabular}{|c|c|c|c|}
\hline Variable & $\begin{array}{c}\text { PEC } \\
\text { Mean } \pm \text { SD }\end{array}$ & $\begin{array}{c}\text { EC } \\
\text { Mean } \pm \text { SD }\end{array}$ & P-value \\
\hline Hb (g/dl) & $9.49 \pm 0.35$ & $8.88 \pm 0.52$ & 0.00 \\
\hline $\begin{array}{c}\text { Serum Ascorbic } \\
\text { Acid (mg/dl) }\end{array}$ & $0.15 \pm 0.09$ & $0.11 \pm 0.06$ & 0.34 \\
\hline $\begin{array}{c}\text { Serum calcium } \\
(\mathrm{mg} / \mathrm{dl})\end{array}$ & $8.24 \pm 0.81$ & $8.03 \pm 0.61$ & 0.64 \\
\hline
\end{tabular}

\section{Discussion:}

The present study investigates the relationship between pre-eclampsia and eclampsia in respect of nutritional factors, socio-economic factors and obstetric factors in selected population of Bangladesh.

Blood biochemical indices was measured in present study. The mean $\mathrm{Hb}$ level of the normal pregnant woman is $10.19 \mathrm{~g} / \mathrm{dl}$, while that of pre-eclamptic patients is $9.49 \mathrm{~g} / \mathrm{dl}$ and that of eclamptic patients is $8.88 \mathrm{~g} / \mathrm{dl}$. The pre-eclamptic and eclamptic patients was found to have lower mean $\mathrm{Hb}$ levels compared to that of the normal pregnant woman. There was found highly significant difference when comparison was made between normal pregnant woman and pre-eclamptic patients, normal pregnant woman and eclamptic patients and pre-eclamptic patients and eclamptic patients. The Hb levels of pre-eclamptic and eclamptic patients were much lower than the normal range (> than $11 \mathrm{~g} / \mathrm{dl}$ ).

The mean serum calcium of normal pregnant woman is $9.84 \mathrm{mg} / \mathrm{dl}$, while that of preeclamptic patients is $8.24 \mathrm{mg} / \mathrm{dl}$ and that of eclamptic patients is $8.03 \mathrm{mg} / \mathrm{dl}$. There was found a significant difference when comparison was made between serum calcium level of normal pregnant woman and pre-eclamptic patients $(\mathrm{p}=0.01)$, and normal pregnant woman and eclamptic patients $(p=0.00)$. It is noted to be that there was found no significant difference when comparison was made between serum calcium level of pre-eclamptic patients and eclamptic patients ( $\mathrm{p}=0.644)$.

The mean serum ascorbic acid level of normal pregnant woman is $0.34 \mathrm{mg} / \mathrm{dl}$, while that of pre-eclamptic patients is $0.15 \mathrm{mg} / \mathrm{dl}$ and that of eclamptic patients is $0.11 \mathrm{mg} / \mathrm{dl}$. There was found no significant difference when comparison was made between serum ascorbic acid level of normal pregnant woman and pre-eclamptic patients $(p=0.09)$, and that of pre-eclamptic patients and eclamptic patients $(p=0.34)$, but significant difference was observed when comparison was made between serum ascorbic acid level of normal pregnant women and eclamptia patients $(\mathrm{p}=0.02)$. It is to be noted that in present study $100 \%$ of both pre-eclamptic and eclamptic patients were found to have serum ascorbic acid level lower than 0.5 $\mathrm{mg} / \mathrm{dl}$ which is considered as the cut off point for the plasma ascorbic acid level. ${ }^{6}$ In 
a previous study, serum ascorbic acid level of pre-eclampsia patients found to be lower than that of normal pregnant mothers. ${ }^{7}$

The overall statistical analysis reveals that lower serum calcium $(<8 \mathrm{mg} / \mathrm{dl})$ level, serum ascorbic acid $(<0.5 \mathrm{mg} / \mathrm{dl})$ and blood $\mathrm{Hb}(<11 \mathrm{~g} / \mathrm{dl})$ level are the first most important determinant of pre-eclampsia and eclampsia.

\section{Conclusion:}

Pre-eclamptic and eclamptic patients in this study may not be true representative of the whole population because the sample size was very small. Therefore some caution should be exercised in Bangladesh. The result of statistical analysis suggests that there are some major factors such as serum calcium, serum ascorbic acid, blood $\mathrm{Hb}$, family income, age, parity and others yet unknown may play important role in determining nutritional status of pre-eclampsia and eclampsia patients. There may be other factors which are responsible for pre-eclampsia and eclampsia. These unknown factors need to be explored in order to address the agony of pre-eclampsia and eclampsia in Bangladesh.

\section{References:}

1. Nelson, W. E. Vanghan V. C. and Mc Kayr R.J. (1969). Text book of pediatrics, W. B. saunders company.

2. Agarwal. S., Dhall., K. and Bhatia., KK (1983). Epidemiologic study of eclampsia. Journal of Obstetrics and Gyneacology of India. Vol: 33,p: 83-89.

3. Menawat, A. J. (1985). Factors affecting Birth weight with special reference to toxaemia of pregnancy, Journal of obstetrics and gyneacology. Vol: 35, No: 1, p: 838-43.

4. Stewart, j. and Schofield, C (1989). The diets of pregnant and post-pregnant women in different social groups in London and Edinburgh: calcium, iron, retinol, ascorbic acid and folic acid.Br-J-Nutr. 62(2): 363-77.

5. Hazra, M.N., Patel, P.S., Bhatt, R. V. and Balmur, R. V (1983). Maternal mortality in Eclampsia at Shree Sayagji, General Hospital, Baroda-10 years Review.

6. James, M. Orten, OHO, W, Neuhams. (1982). Nutrition: Normal and Clinical in human biochemistry, $10^{\text {th }}$ ed. The C.V. Mosby Co. London, p: 684-807.

7. Mikhail, M.S., Anyaegbunum, A., Garfinkel, D., Palan, P.R., Basu, J. and Rommey, S.L (1994). : Pre-eclampsia and antioxidant nutrients : decreased plasma levels of reduced ascorbic acid, alpha tocopherol and $\beta$-carotene in women with pre-eclampsia. American journal of obstetrics and gyneacology. 1971 (1). 150-57.

8. Cartwright, G. E., Diagnostic Laboratory Hematology, $4^{\text {th }}$ ed., Gruce \& Stratton, Inc., New York, N.Y., 1968, p-318 \& 369.

9. Stern, J., Lewis, W.H.P. (1957). The colorimetric estimation of calcium in serum with ocresolphthalein complexone. Clinica Chimica Acta. Vol: 2, Issue: 6, p-576-80.

10. Lowry OH, Lopez JA, Bessey OA. The determination of ascorbic acid in small amount of blood serum. J Biol Chem 1945; 160: 609-15. 